\title{
ANALYSIS OF AIRY POINT APPLICATION ON LINE SCALE CALIBRATION IN
} RCM LIPI

\author{
Analisa Aplikasi Titik Airy pada Kalibrasi Line Scale di RCM-LIPI
}

\author{
Nadya Larasati Kartika dan Nurul Alfiyati \\ Length Metrology, Research Center for Metrology, Indonesian Institute of Sciences (LIPI) \\ South Tangerang, Indonesia \\ e-mail: nadya.larasati.kartika@lipi.go.id
}

Diterima: 25 Juli 2018, Direvisi: 15 Oktober 2018, Disetujui: 17 Oktober 2018

\begin{abstract}
Calibration of line scale in the Research Center for Metrology LIPI Indonesia (RCM-LIPI) can be measured using two methods, first, with or laser interferometer. Second, using Ine dimensional measuring machine (SIP machine) which is calibrated and traceable to the laser interferometer. Although line scale calibrated using laser interferometer, the system needs SIP machine table as the base on line scale. Capability of the SIP machine table covers only up to $400 \mathrm{~mm}$ and for line scale above $400 \mathrm{~mm}$, measurement can be extended to $1000 \mathrm{~mm}$ using shifting methods. The alignment process is needed to minimize the error because of misalignment to the end at the end surfaces due to imperfect straightness. Supporting point as a method to maintain line scale still straight during measurement should be applied on SIP machine table during measurement process. For line scale ranged $400 \mathrm{~mm}$, supporting point can be attached because the whole artefact is on the table, while some of the industrial instruments have scales above $400 \mathrm{~mm}$, this mean slightly difficult to attach supporting point. As for the supporting points, airy points were used, because they were the most suitable for line scales with the pattern at the top plane. This paper described an appropriate supporting points setting and their influence in line scale calibration ranged $500 \mathrm{~mm}$ by designed two systems supporting point attachment based on airy point formula calculation, they are located symmetrically $0,577 \mathrm{~L}$ apart, with $\mathrm{L}=500 \mathrm{~mm}$ and $\mathrm{L}=350 \mathrm{~mm}$, using SIP machine method. Each design is analysed using error graph and $E_{n}$ score to determine the most suitable design for 500 $\mathrm{mm}$ line scale calibration. It was found that airy point as supporting point with $L=500 \mathrm{~mm}$ in line scale calibration giving proximity with slope of graph $2.5 \times 10^{-6}$ and $100 \%$ consistency based on comparison with nominal values and $E_{n}$ score.
\end{abstract}

Keywords: line scale, airy point, $E_{n}$ score

\begin{abstract}
Abstrak
Kalibrasi line scale di Pusat Penelitian Metrologi LIPI Indonesia (RCM-LIPI) dapat diukur menggunakan dua jenis metode, pertama menggunakan laser interferometer. Kedua, menggunakan mesin pengukuran satu dimensi (mesin SIP) dan yang tertelusur dan terkalibrasi ke laser interferometer. Meskipun kalibrasi line scale menggunakan laser interferometer, sistemnya membutuhkan meja mesin SIP sebagai tempat penyimpanan line scale. Kemampuan meja ukur hanya mampu menampung artefak hingga $400 \mathrm{~mm}$ dan untuk yang lebih dari 400 $\mathrm{mm}$, pengukuran dapat diperpanjang sampai $1000 \mathrm{~mm}$ menggunakan metode pergeseran. Pengaturan kelurusan pengukuran sangat diperlukan untuk meminimalisir kesalahan karena ketidaksejajaran kedua ujung permukaan akibat kelurusan pada artefak itu sendiri. Metode penggunaan titik bantu yang dipasang pada meja adalah untuk memastikan bahwa line scale tetap lurus selama proses kalibrasi harus diaplikasikan. Untuk line scale dengan skala $400 \mathrm{~mm}$ pemasangan titik bantu dapat dilakukan karena seluruh badan artefak berada pada meja ukur, sedangkan peralatan yang dimiliki oleh industri memiliki skala di atas $400 \mathrm{~mm}$. Titik bantu yang digunakan dalam makalah ini adalah jenis titik Airy, karena metode tersebut merupakan metode yang sesuai untuk line scale. Makalah ini menjelaskan tentang pengaturan pemasangan titik bantu dan pengaruhnya terhadap hasil kalibrasi line scale dengan skala $500 \mathrm{~mm}$ dengan mendesain dua sistem pengaplikasian titik bantu berdasarkan perhitungan rumus Airy, lokasi pemasangan kedua titik bantu berada pada jarak 0,577 L secara simetris, dengan $L=500 \mathrm{~mm}$ dan $L=350 \mathrm{~mm}$ dengan metode menggunakan mesin SIP. Setiap desain dianalisa menggunakan grafik kesalahan dan nilai $E_{n}$ untuk menentukan desain yang paling sesuai untuk kalibrasi line scale dengan skala $500 \mathrm{~mm}$. Hasil penelitian menunjukan bahwa pemasangan titik bantu airy pada desain $L=500$ $\mathrm{mm}$ memberikan hasil kedekatan terhadap nilai nominal dengan nilai kemiringan grafik $2,5 \times 10^{-6}$ dan $100 \%$ kekonsistenan berdasarkan perbandingan hasil ukur terhadap nilai nominal dan nilai $E_{n}$
\end{abstract}

Kata kunci: line scale, titik Airy, nilai $E_{n}$ 


\section{INTRODUCTION}

Competency test result of dimensional quality assessment on manufacture products in a vocational high school in Indonesia is only as low as $20 \%$ which meets industry standard [1]. This result may impact on the difficulty of Indonesian local manufacture products to compete in international market. To lift up their competitiveness, the products have to be manufactured ideally. There are a lot of parameters to determine the ideals of a manufacture product, such as conformance with the specifications, long periods of reliability and has ability to meet industrial requirements [2]. Measurement and calibration are among the concern of this research. The philosophies behind this are the importance of measurement process to produce the product that meets the design requirement, and also to maintain the quality of performance. In order to manufacture an ideal product, a precision measuring instrument is required to accurately measure its shape and size. Line scale is one of several measuring instruments frequently used in industry, academic and forefront technology, for example in the micro-electronics and machine tool industries [3], hence calibration of the instruments is required to ensure the traceability. Calibration of line scale in the Research Center for Metrology LIPI Indonesia (RCM-LIPI) is traceable to one dimensional measuring machine (SIP machine) which is calibrated and traceable to the laser interferometer for working standard scale type, and laser interferometer for reference standard scale type, both measurement use SIP machine as an optics component and the base of line scale using SIP machine table. In precision linescale interferometers, a photoelectric microscope is used for observation of the graduation lines [4].

Capability of the SIP machine table used as the base of line scale, however, covers only up to $400 \mathrm{~mm}$, while some of the industrial instruments have scales above this size. To compensate this limitation, the artifact has to be able to be shifted gradually during the measurement process. Since there has to be more than one shifting action for each artifact, then several values of uncertainties are formed depending on the number of the shifting.

Line scale calibration in RCM-LIPI is conducted without using any supporting point to minimize artifact sag due to gravitation. Based on final report of EUROMET Key Comparison, EUROMET.L-K7 2006, supporting point was applied by other national metrology institutes (NMIs) even for a very short scale around 100 $\mathrm{mm}$ [5]. However, several publications explained that supporting points for short scale are not needed, because the method of supporting a scale only influences the long ones [6]. Sawyer et al. also explained that error without supporting point in very short scales is negligible, however ignoring this error in long artifact above $700 \mathrm{~mm}$ may give a slight bend or some combination of these geometric errors [7]. However, the imperfect flatness of SIP machine table also gives an error to the measurement result, surface flatness SIP machine table can be measured using SIP machine to evaluate the SIP machine table topography [8]. There are several supporting points methods in length calibration, they are Bessel points, Airy points, Flat support, and other supports points [6].

To improve the knowledge about supporting point influence to the result of calibration, examinations have been carried out by taking some calibrations using several parameters into account. There is no single published paper concerning with supporting point for line scales those have to be measured by shifting method yet. This paper describes an appropriate supporting points setting and their influence in line scale calibration ranged $500 \mathrm{~mm}$ by shifting methods particularly. As for the supporting points, airy points are used, because they are the most suitable for line scales with the pattern at the top plane [9].

\section{BASIC THEORY}

Linear graduation is usually used in length instruments. It can identify linear measures such as inches, or millimeters. Line scale calibration is conducted from first until the last graduation scale. The longer the scale, the more susceptible to bending caused by the weight of the scale itself and to getting geometric error.

Accuracy in length instrument measurement and calibration is necessary to be well considered. One of some parameters to determine the accuracy of the calibration is the straightness of the unit under test (UUT), in this case is the line scale. The alignment process is needed to minimize the error due to imperfect straightness. It does not only apply for $x$ and $y$ axes but also for $z$ axis in accordance with gravitational force due to the weight of the line scale.

To obtain information about straightness, a straightness reference is used. The straightness references can be divided in two categories: mechanical and optical types [9]. The fundamental difference between them is that the former consists of particles (atoms) that are arranged in a more or less known way, while the later makes use of 'free' particles those are travelling in a more or less well-defined way [9]. A 
rectangular bar is used as a mechanical straightness reference. As a matter of fact, any bar can be used as long as it has a flat surface to maintain the stability of the line scale. Table 1 shows the deviation of line scale which relates to the accuracy classes of straightness reference according to the DIN 874 norm [10].

Table 1 Classification of the deviation of straightness references to the accuracy classes based on DIN 874, in which $L$ is the length of the straightness reference in $\mathrm{mm}$.

\begin{tabular}{cc}
\hline Class & Maximum Deviation $(\mathrm{m})$ \\
\hline 00 & $1+\mathrm{L} / 500$ \\
0 & $2+\mathrm{L} / 100$ \\
1 & $4+\mathrm{L} / 60$ \\
2 & $8+\mathrm{L} / 40$ \\
\hline
\end{tabular}

The straightness references are positioned under the line scale as supporting points. The mounting of these elements gives two problems. The first of these, both end faces of the line scale will appear to deviate from parallel because of sag in the vicinity of the end of the scale and, the second, the measured scale will be somewhat shorter than it should be because of extra bending of the material [11]. To minimize the risk due to the misplacing of supporting points, there are several methods those can be selected from. They are Bessel points which are symmetrically located $0,544 \mathrm{~L}$ apart, where $\mathrm{L}$ is the length of the scale body; airy points which are located symmetrically $0,577 \mathrm{~L}$ apart; minimum bending points which are located $0,2232 \mathrm{~L}$ from the end of the body scale; and finally zero deflection in the middle point which are located $0,2386 \mathrm{~L}$ from the end of the body scale [6], [9]. Airy points are used as a method to place supporting points because it provides parallel end surfaces and usually used for long end gauge and line scales with the pattern on the top plane [9].

Since the universal measuring machine as the standard devices in RCM-LIPI has limited range to $400 \mathrm{~mm}$, the shifting process is needed to accommodate longer measurands, which in this research is up to $500 \mathrm{~mm}$. This shifting process causes the problem of airy point placement later. Before designing the proper placement of airy point incorporating the shifting process, the preliminary measurement is needed by taking some consideration into account, among others the literature about how important airy point application in any line scale measurement not only from $700 \mathrm{~mm}$ range [7] but also from $100 \mathrm{~mm}$ range.

Preliminary calibration has been conducted using $300 \mathrm{~mm}$ of line scale with two methods, i.e. using airy points and non-airy points. Line scale $300 \mathrm{~mm}$ was used for preliminary measurement is to avoid the shifting process due to the limitation of the length of the table. After making comparison among the results, line scale calibration using airy point gives less slope of $57,4 \%$ than the other method as shown in Figure 1. These means, that the airy point gives more accurate values. Based on this result, deeper examination of line scale calibration is needed due to airy point influence to accuracy, not only for above $700 \mathrm{~mm}$ as literature stated [11] but also below $700 \mathrm{~mm}$ especially when shifting methods applied.

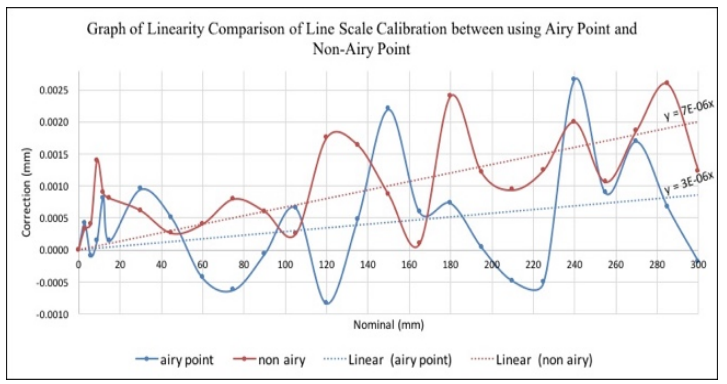

Figure 1 Linearity comparison between line scale calibration using airy point and non airy point on $300 \mathrm{~mm}$ scale (smooth curve is to help reader).

Data analysis were done using En score as describes in ISO 13528:2015. ISO 13528 is the standard for the statistical methods used in proficiency tests. En score are normalized deviations commonly used in comparing two results of measurement of the same quantity [12].

A definition in the context of a measurement result and expanded uncertainty respectively are xlab and Ulab provided by RCMLIPI and xref and Uref by reference laboratory. The En score is defined as follow based on one given by Wöger [13] :

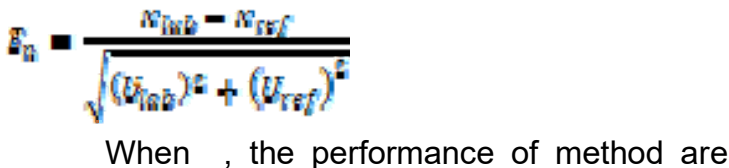
evaluated as an indication "consistent" and "inconsistent" respectively [12], [14].

\section{METHODS}

The unit under test is a Mitutoyo standard scale of $500 \mathrm{~mm}$ in range, the standard devices are universal measuring machine (SIP Machine $414 \mathrm{M})$ which is calibrated and traceable to the definition of meter. Measurement process is conducted in a specific environment as follows; $20^{\circ} \pm 0.5^{\circ} \mathrm{C}$ for temperature and $55 \pm 10 \%$ for relative humidity. Line scale measurement setting generally is shown in Figure 2, in this figure the measurement setting using supporting points. Sliding table will travel smoothly by rotating the gears system from $0-400 \mathrm{~mm}$ with the resolution of the machine $0.0005 \mathrm{~mm}$. The graduation line 
was detected by microscope with 81 times magnification.

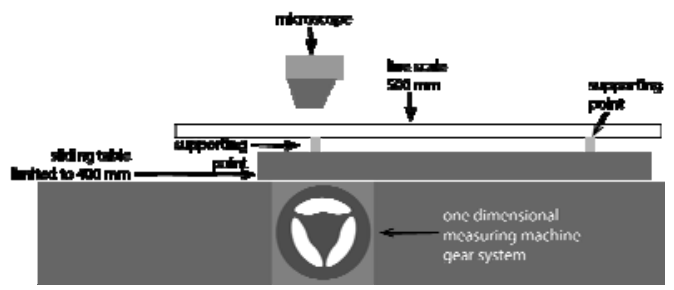

Figure 1 Line scale calibration system using 500 $\mathrm{mm}$ standard scale

Three designs of measurement are shows in Figure 3. Figure 3 (a) shows the measurement without airy point, the line scale is simply rested on the machine table, Figure 3 (b) shows line scale measurement using airy point within range $500 \mathrm{~mm}(\mathrm{~L}=500 \mathrm{~mm})$, the points were attach positioned under the line scale at around $106 \mathrm{~mm}$ and $394 \mathrm{~mm}$. Two pieces of gauge block of the same nominal size were used as the supporting points, the size of the gauge block were randomly selected since there was no literature mentioning the ideal height of supporting point.

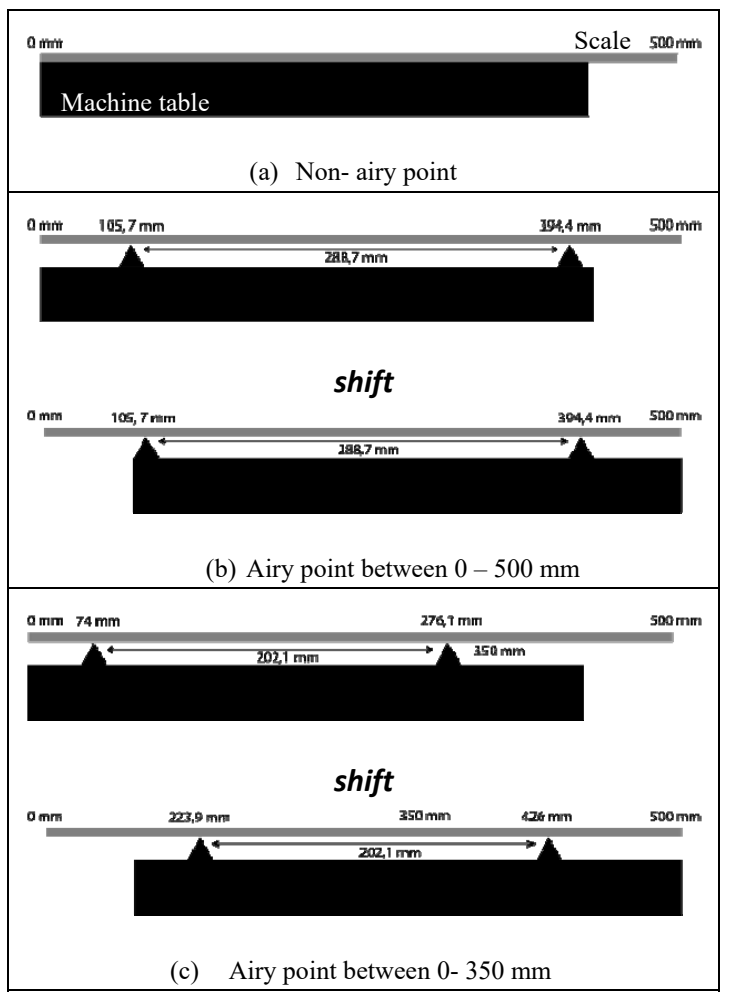

Figure 2 Line scale measurement setting. (a) Without airy point (b) With airy point between 0-
$500 \mathrm{~mm}$, and (c) With airy point between 0-350 $\mathrm{mm}$.

Airy point implementation in standard scale $500 \mathrm{~mm}$ can still be attached on the limited table machine, the problem is when the standard scale above $500 \mathrm{~mm}$, the airy point implementation will not attach on the limited table machine anymore. Another position of airy point is needed to find a proper design when airy point couldn't attach on the table machine. Figure 3 (c) shows line scale measurement using airy point within measurement point scale. Based on the work instruction of line scale measurement in RCM-LIPI for artifact which have range above $400 \mathrm{~mm}$, there are several connection points for shifting process; they are 350 and $700 \mathrm{~mm}$. It means when range $0-350 \mathrm{~mm}$ were measured, then the supporting point applied with $L=350 \mathrm{~mm}$ calculation and attached between 0-350 mm range. However, when the line scale shifted and range $350-500 \mathrm{~mm}$ were measured, then the supporting point attached between 150 - 500 $\mathrm{mm}$.

Center to center measurement method was used for line scale measurement process since the graduation thickness was very small and therefore gave no possibility to use edge to edge measurement method measurement. This method conforms with the work instruction of line scale measurement in RCM-LIPI. There will be 51 data points for each measurement, the data were taken three times for each points using bidirectional taking data method. Measurement data process and analysis were done using statistical graph software.

\section{RESULTS AND DISCUSSIONS}

In this paper, three designs line scale measurement they are without airy point, with airy point with $L=500 \mathrm{~mm}$ and $\mathrm{L}=350 \mathrm{~mm}$ and they were compared and the results are shown in Figure 4. Figure 4 summarized proximity measurement values of each design to the nominal values as reference without involving uncertainty values. Starting from the slope of the curve, line scale measurement using airy point with $L=500 \mathrm{~mm}$ (the orange line) is the smallest value of slope than the other. Slope value of line scale measurement using airy point with $L=500$ $\mathrm{mm}$ is $63,4 \%$ smaller than line scale measurement without airy point (the blue line) and $56,1 \%$ smaller than line scale measurement using airy point with $L=350 \mathrm{~mm}$ (the gray line). 


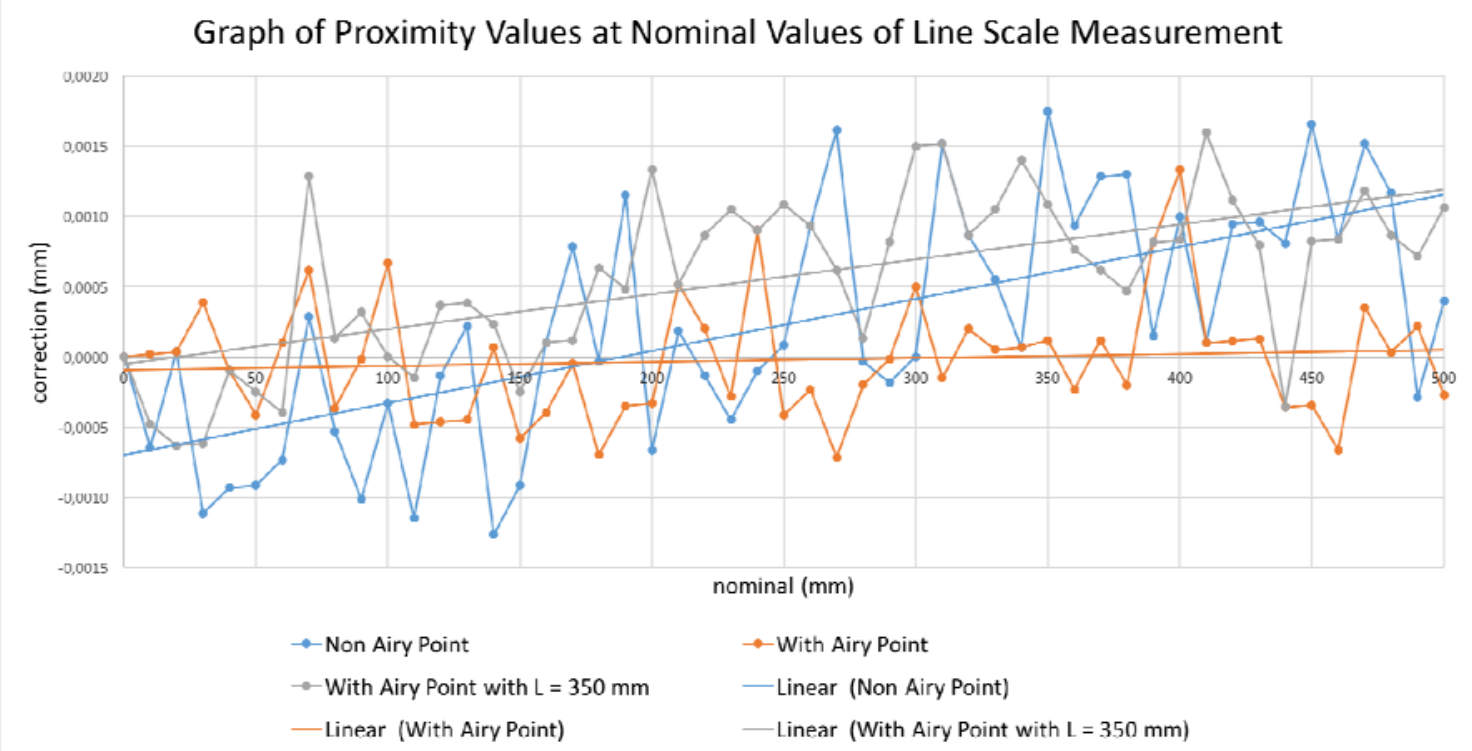

Figure 4 Deviation of line scale calibration between three measurement design.

Table 1 Slope value for three designs of line scale calibration system.

\begin{tabular}{ll}
\hline Condition & Slope \\
\hline Without airy point & $3.7 \times 10^{-6}$ \\
With airy point $\mathrm{L}=500 \mathrm{~mm}$ & $2.9 \times 10^{-7}$ \\
With airy point $\mathrm{L}=350 \mathrm{~mm}$ & $2.5 \times 10^{-6}$ \\
\hline
\end{tabular}

Table 2 shows slope value between three designs. To determine the proximity of measurement results to the nominal measurement values, the value of slope was used. The smaller slope giving indication that the result is closer to the nominal measurement values. This result shows that line scale measurement with airy point with $\mathrm{L}=500 \mathrm{~mm}$ is more proximate than without using any airy point.

Table 2 Expanded uncertainty for each methods.
Even tough line scale calibration using airy point did not give the same result between $L$ $=500 \mathrm{~mm}$ and $\mathrm{L}=350 \mathrm{~mm}$, basically the use airy point gives better proximity than without using airy point. However, this statement is given just based on the slope value from error graph.

To determine the proper design using airy point, further analysis is needed. Measurement results of all methods were compared to reference result from Mitutoyo calibration laboratory. Table 3 shows expanded uncertainty for each method. En score was obtained from calculation measurement result and expanded uncertainty between the reference value and the proposed method.

\begin{tabular}{|c|c|c|c|c|}
\hline \multirow[b]{3}{*}{$\begin{array}{c}\text { Nominal } \\
(\mathrm{mm})\end{array}$} & \multicolumn{4}{|c|}{ Uncertainty } \\
\hline & Reference & & osed Metho & \\
\hline & $\begin{array}{l}\text { JCSS Mitutoyo } \\
(\mu \mathrm{m})\end{array}$ & $\begin{array}{c}\text { Without airy } \\
\text { point } \\
(\mu \mathrm{m})\end{array}$ & $\begin{array}{c}\text { With airy } \\
\text { point } \\
\mathrm{L}=500 \mathrm{~mm} \\
(\mu \mathrm{m})\end{array}$ & $\begin{array}{c}\text { With airy } \\
\text { point } \\
\mathrm{L}=350 \mathrm{~mm} \\
(\mu \mathrm{m})\end{array}$ \\
\hline $0-300$ & $(0.10+0.12 . L / 1000)$ & - & - & - \\
\hline $0-350$ & - & 1.68 & 1.60 & 1.73 \\
\hline $350-500$ & $(0.10+0.25 . L / 1000)$ & 2.37 & 2.25 & 2.45 \\
\hline
\end{tabular}

$\mathrm{L}$ : Scale length in $\mathrm{mm}$

$E_{n}$ score was compared for each points of each method. Table 4 shows $E_{n}$ score from each method and compared of each data point. This table indicates that the most consistent measurement value between the proposed method and the reference value for each measurement point.

There is $38 \%$ data points which are consistent with reference result from using nonairy points method. For using airy points with $L=$
$500 \mathrm{~mm}$ method has $60 \%$ data points which are consistent with reference result and $2 \%$ data points are consistent in using airy point with $\mathrm{L}=$ $350 \mathrm{~mm}$ methods.

Even though line scale calibration using airy point with $L=350 \mathrm{~mm}$ give better proximity measurement values at nominal than without using airy point from the slope analysis but in $E_{n}$ score, airy points with $L=350 \mathrm{~mm}$ methods more than $90 \%$ has inconsistent result. Since the 
reference measurement values for measurement comparison were different, those discrepancy result appeared. Most notably, proximity measurement values do not involve the uncertainty value, only measurement values and nominal. While the result of $E_{n}$ score using calibration result from fabric as reference, which involving uncertainty value and deviation from the reference values.

Table $3 E_{n}$ score for each methods and each nominal measurement

\begin{tabular}{|c|c|c|c|}
\hline \multirow[b]{2}{*}{$\begin{array}{c}\text { Nominal } \\
(\mathrm{mm})\end{array}$} & \multicolumn{3}{|c|}{$E_{n}$ Score } \\
\hline & $\begin{array}{l}\text { Without } \\
\text { airy point }\end{array}$ & $\begin{array}{c}\text { With airy } \\
\text { point } \\
\mathrm{L}=500 \mathrm{~mm}\end{array}$ & $\begin{array}{c}\text { With airy } \\
\text { point } \\
\mathrm{L}=350 \\
\mathrm{~mm}\end{array}$ \\
\hline 0 & 0.00 & 0.00 & 0.00 \\
\hline 10 & 0.35 & 0.05 & 3.98 \\
\hline 20 & 0.10 & 0.11 & 4.64 \\
\hline 30 & 0.62 & 0.29 & 5.05 \\
\hline 40 & 0.52 & 0.03 & 0.38 \\
\hline 50 & 0.50 & 0.22 & 1.70 \\
\hline 60 & 0.37 & 0.13 & 2.73 \\
\hline 70 & 0.21 & 0.43 & 12.73 \\
\hline 80 & 0.26 & 0.17 & 2.19 \\
\hline 90 & 0.59 & 0.01 & 3.26 \\
\hline 100 & 0.22 & 0.40 & 0.29 \\
\hline 110 & 0.72 & 0.34 & 1.98 \\
\hline 120 & 0.14 & 0.36 & 2.50 \\
\hline 130 & 0.11 & 0.30 & 3.32 \\
\hline 140 & 0.81 & 0.02 & 1.25 \\
\hline 150 & 0.58 & 0.40 & 2.93 \\
\hline 160 & 0.05 & 0.26 & 0.74 \\
\hline 170 & 0.49 & 0.01 & 1.46 \\
\hline 180 & 0.00 & 0.42 & 6.32 \\
\hline 190 & 0.70 & 0.20 & 4.82 \\
\hline 200 & 0.36 & 0.17 & 13.10 \\
\hline 210 & 0.16 & 0.38 & 5.69 \\
\hline 220 & 0.03 & 0.18 & 8.99 \\
\hline 230 & 0.23 & 0.14 & 10.43 \\
\hline 240 & 0.00 & 0.63 & 9.39 \\
\hline 250 & 0.10 & 0.21 & 11.02 \\
\hline 260 & 0.55 & 0.15 & 8.76 \\
\hline 270 & 0.97 & 0.44 & 5.97 \\
\hline 280 & 0.06 & 0.16 & 0.67 \\
\hline 290 & 0.14 & 0.04 & 7.20 \\
\hline 300 & 0.02 & 0.34 & 14.47 \\
\hline 310 & 0.95 & 0.05 & 15.00 \\
\hline 320 & 0.51 & 0.12 & 10.94 \\
\hline 330 & 0.35 & 0.06 & 13.93 \\
\hline 340 & 0.13 & 0.14 & 19.94 \\
\hline 350 & 1.15 & 0.19 & 16.14 \\
\hline 360 & 0.45 & 0.05 & 11.70 \\
\hline 370 & 0.60 & 0.16 & 9.65 \\
\hline 380 & 0.59 & 0.06 & 7.35 \\
\hline 390 & 0.10 & 0.57 & 11.57 \\
\hline 400 & 0.43 & 0.86 & 11.02 \\
\hline 410 & 0.01 & 0.02 & 18.77 \\
\hline 420 & 0.30 & 0.07 & 11.27 \\
\hline 430 & 0.35 & 0.00 & 8.47 \\
\hline 440 & 0.30 & 0.29 & 5.89 \\
\hline 450 & 0.66 & 0.27 & 9.49 \\
\hline 460 & 0.34 & 0.43 & 10.44 \\
\hline 470 & 0.63 & 0.21 & 15.02 \\
\hline 480 & 0.53 & 0.08 & 12.22 \\
\hline 490 & 0.09 & 0.18 & 10.14 \\
\hline
\end{tabular}

\begin{tabular}{c|ccc}
\hline $\begin{array}{c}\text { Nominal } \\
(\mathrm{mm})\end{array}$ & $\begin{array}{c}\text { Without } \\
\text { airy point }\end{array}$ & $\begin{array}{c}\text { With airy } \\
\text { point } \\
\mathrm{L}=\mathbf{5 0 0} \mathbf{~ m m}\end{array}$ & $\begin{array}{c}\text { With airy } \\
\text { point } \\
\mathrm{L}=\mathbf{3 5 0} \\
\mathbf{m m}\end{array}$ \\
\hline 500 & 0.22 & 0.08 & 15.36 \\
\hline
\end{tabular}

There is $38 \%$ data points which are consistent with reference result from using nonairy points method. For using airy points with $L=$ $500 \mathrm{~mm}$ method has $60 \%$ data points which are consistent with reference result and $2 \%$ data points are consistent in using airy point with $L=$ $350 \mathrm{~mm}$ methods.

Even though line scale calibration using airy point with $L=350 \mathrm{~mm}$ give better proximity measurement values at nominal than without using airy point from the slope analysis but in $E_{n}$ score, airy points with $L=350 \mathrm{~mm}$ methods more than $90 \%$ has inconsistent result. Since the reference measurement values for measurement comparison were different, those discrepancy result appeared. Most notably, proximity measurement values do not involve the uncertainty value, only measurement values and nominal. While the result of $E_{n}$ score using calibration result from fabric as reference, which involving uncertainty value and deviation from the reference values.

In conclusion the results show that the most consistent value between the methods and the reference value is using airy point with $L=500$ $\mathrm{mm}$ methods with consistency $100 \%$ and smallest proximity values with $2.5 \times 10^{-6}$ of graph slope.

\section{CONCLUSION}

Based on two parameter analysis, slope value analysis and $E_{n}$ score analysis, line scale calibration giving proximity measurement values with $2.5 \times 10^{-6}$ of graph slope at nominal values and consistency $100 \%$ when using airy points with $\mathrm{L}=500 \mathrm{~mm}$ as a method in line scale calibration.

\section{ACKNOWLEDGEMENT}

Authors would like thank Prof. Jimmy Pusaka and length laboratory RCM-LIPI members for helping in measurement setting, data analyse and discussion about this paper. And also It would be better to acknowledge the funding provider here.

\section{REFERENCES}

[1] R. C. Putra, U. K.- Karo, and Purnawan. (2015). Analisis Penilaian Kualitas Dimensi Produk Uji Kompetensi Keahlian Teknik Permesinan di SMK," J. Mech. Eng. Educ., vol. 2, no. 1, pp. 98-105.

[2] D. A. Garvin. (1987). Competing on the 
Eight Dimensions of Quality, Harvard Business review, pp. 1-23, Dec-1987.

[3] J. S. Beers and K. B. Lee (1982). "Interferometric measurement of length scales at the National Bureau of Standards," Precis. Eng., vol. 4, pp. 205214, 1982.

[4] A. Lassila, E. Ikonen, and K. Riski (1994). "Interferometer for calibration of graduated line scales with a moving CCD camera as line detect," Appl. Opt., vol. 33, no. 16, pp. 3600-3603

[5] "EURAMET.L-K7 Key Comparison Calibration of line scales," 2006.

[6] S. Beers, John, "Length scale measurement procedures at the national bureau of standard," Gaithersburg, 873625, 1987.

[7] D. Sawyer, B. Parry, S. Phillips, C. Blackburn, and B. Muralikrishnan, "A model for geometry-dependent errors in length artifacts," J. Res. Natl. Inst. Stand. Technol., vol. 117, pp. 216-230, 2012.

[8] O. Novyanto and E. Pratiwi, "A preliminary study to evaluate the topography of narrow surface plate," Instrumentasi, vol. 39, pp. 1-8, 2015.

[9] G. Nijsse, "Linear motion systems; a modular approach for improved straightness performance," Technische Universiteit Delft, 2001.

[10] "DIN 874-1 Straightedges - Part 1: Steel straight edges - Dimensions and technical delivery conditions," 2003.

[11] A. J. Lewis, "Absolute length measurement using interferometry," University of London, 2002.

[12] M. G. Cox, "The evaluation of key comparison data: determining the largest concictent subset," Metrologia, vol. 44, pp. 187-200, 2007.

[13] W. Wöger, "Remarks on the En criterion used in measurement comparisons," PTBMitteilungen, vol. 109, pp. 24-7, 1999.

[14] K. Shirono, M. Shiro, H. Tanaka, and K. Ehara, "Proficiency tests with uncertainty information: Analysis using the maximum likelihood method," vol. 5, no. 3, pp. 1623, 2016. 